Spring 2016

\title{
Have Changes in Business Practices and Reporting Standards Changed the Taxonomy of Financial Ratios?
}

Thomas Zeller

Loyola University Chicago, tzeller@luc.edu

John Kostolansky

Loyola University Chicago

Michail Bozoudis

Follow this and additional works at: https://ecommons.luc.edu/business_facpubs

Part of the Business Commons

\section{Author Manuscript}

This is a pre-publication author manuscript of the final, published article.

\section{Recommended Citation}

Zeller, Thomas; Kostolansky, John; and Bozoudis, Michail. Have Changes in Business Practices and Reporting Standards Changed the Taxonomy of Financial Ratios?. American Journal of Business, 31, 2: 85-97, 2016. Retrieved from Loyola eCommons, School of Business: Faculty Publications and Other Works, http://dx.doi.org/10.1108/AJB-10-2015-0030

This Article is brought to you for free and open access by the Faculty Publications and Other Works by Department at Loyola eCommons. It has been accepted for inclusion in School of Business: Faculty Publications and Other Works by an authorized administrator of Loyola eCommons. For more information, please contact ecommons@luc.edu.

\section{cc) (†) $\ominus$}

This work is licensed under a Creative Commons Attribution-Noncommercial-No Derivative Works 3.0 License. (c) Emerald Group Publishing 2016 


\title{
Have Changes in Business Practices and Reporting Standards Changed the Taxonomy of Financial Ratios?
}

\begin{abstract}
Prior research established a seven dimension taxonomy of financial ratios. Arguably, advances in business practices, changes in financial reporting standards, and technology have affected the underlying relationships of this taxonomy. This study proposes to identify the extent to which the previously identified relationships have changed, and, if appropriate, to establish an entirely new taxonomy of manufacturing industry financial ratios.

In addition, this study substantially improves and extends prior work in two areas. First, it utilizes advanced statistical methodologies and computing technologies that were unavailable to previous researchers. Second, it investigates not only the current taxonomy of manufacturing industry financial ratios, but also its stability over a recent ten year period.

Our findings indicate that eleven factors now comprise the financial ratio taxonomy. Notably, a separate cash flow factor did not surface in this study as was the case in earlier work; rather, cash flow ratios correlated with accrual-based measures. Finally, our study identified a new current position factor.
\end{abstract}




\section{Introduction}

Researchers and analysts rely upon classifications of financial ratios to determine which ratios are appropriate for answering specific financial analysis questions. Thirty-five years ago, researchers empirically established a taxonomy that has remained the status quo despite the adoption of innovative business practices, new financial reporting standards, and internationalization of business. We question whether these changes have significantly altered the composition of financial statement data and their fundamental relationships.

For example, technological innovation has supported the development of enhanced cash flow and inventory management systems, allowing firms to significantly reduce their cash and inventory balances. The Financial Accounting Standards Board (FASB) has mandated two new financial statements: the Statement of Cash Flows and the Statement of Comprehensive Income. Additionally, new FASB standards mandated that certain balance sheet items must be valued at fair market value (rather than cost) with the corresponding changes in market value identified as unrealized gains and losses in the comprehensive income statement. This disjointed recognition required the creation of a new category of equity on the balance sheet called Accumulated Other Comprehensive Income and Loss (AOCI). Significant amounts of AOCI arise from changes in pension plans' funded status and adjustments from foreign currency translation. These are but a few examples of the changes that have taken place.

Given the above, researchers and analysts should logically ask, “Are we using an outdated taxonomy?” It seems probable that the fundamental relationships underlying the taxonomy have been impacted by these changes, and continued reliance on the taxonomy is unwarranted if its structure has become unstable (Altman and Eisenbeis, 1978; Barnes, 1987). 
Thus, the primary focus of this study is to investigate if and how the financial ratio taxonomy has changed.

Because the changes in business practices and financial reporting rules impact many interconnected financial statement variables, it is impossible to specifically predict how the relationships among financial ratios have actually changed. That said, we offer examples of the potential impact of the aforementioned changes.

For example, total current assets is a component of several commonly used metrics such as the current ratio, current asset turnover ratio, and working capital. Current assets include cash, accounts receivable, and inventory—-three major components that have been affected by technology and business practices. Cash management software and electronic money transfers enable businesses to thrive with smaller cash balances. The widespread use of debit and credit cards speed the cash collection process. Customer relationship management programs enhance the monitoring of receivables by customer, region, and/or product category and allow management to identify and respond to sales and payment pattern changes more quickly. The end result is faster turns, lower balances and fewer write offs. Similar technological improvements allow management to shorten the delivery cycle, turn inventory quickly and operationalize just-in-time inventory techniques. These improvements reduce the required investment in current assets, thus reducing the necessary amount of debt or equity financing for the firm. All these changes may reduce the prominence of the current ratio for measuring liquidity. Might liquidity now be better captured by a simple cash-based measure, such as cash/current debt? The present study can shed light on that question.

Likewise, the receivable turnover and inventory turnover ratios will report increased values if technology enables firms to collect receivables faster and to reduce inventory. Can 
systemic shifts in the turnover values alter their relationships to each other and to other ratios? We are unable to deduce the answer and we rely on this study to help resolve the question.

Total assets is a widely used component of financial ratios, such as net income to total assets, total liabilities to total assets, operating cash flows to total assets and net sales to total assets. Changes in business practices have affected total assets in several ways. Outsourcing reduced the need for investment in equipment, thus reducing total assets. Asset management systems have likely reduced the amounts of cash, receivables, and inventory while increasing long-term assets by the cost of such systems. Additionally, new financial reporting requirements have impacted the reported amount of total assets. For example, goodwill impairment testing has replaced amortization. In the absence of an impairment, total assets will be higher than previously reported under the amortization regime; however, a major impairment could produce the opposite outcome. Similarly, the requirement to report certain balance sheet items at their fair market values produces an unpredictable impact on the balance sheet, as both unrealized gains and losses are reflected. What is observable, however, is that the magnitude of these gains and losses is often quite large as they are related to the valuation of defined benefit pension assets and liabilities, translation of foreign subsidiary balance sheets back to U.S. dollars, and certain hedging transactions undertaken by the firm. Not only can these amounts be quite large, they can also be volatile from year to year. Ratios with total assets as a component may be greatly changed in either direction. Again, we must rely on the present study to provide evidence of any changes to the taxonomy.

Not only have accounting standards changed, new financial statements have been enacted. In November of 1987 the Financial Accounting Standards Board (FASB) issued Financial Accounting Standard (FAS) 95, The Statement of Cash Flows. The standard 
specifically defined operating, investing and financing cash flows. Subsequently, cash flow ratios such as operating cash flows to sales and operating cash flows to total assets have become common performance measures. Consequently, we believe that the informational content of these cash flow ratios deserves further study.

Our primary focus here is to investigate if and how the taxonomy of financial ratios has changed under current business practices and financial reporting guidelines. Have any or all of the original factors survived the changes? Have new factors emerged from the changes? Are the factors stable across this taxonomy? Similar questions drove the original taxonomic research. The following sections review the literature, describe the research design, discuss the findings, and provide concluding comments.

\section{Literature Review}

Numerous studies have investigated the empirical relationship among financial ratios. These works collectively established the taxonomy of financial ratios in use today. Some were motivated by a desire to predict bond ratings or bankruptcy while others were simply interested in the underlying relationship of financial ratios.

Pinches and Mingo (PM, 1973) were interested in predicting industrial bond ratings using a reduced set of financial ratios and bond related company attributes. PM found 35 ratios and attributes could be reduced to six attributes to predict company bond ratings. Pinches, Mingo, and Caruthers (PMC, 1973) focused on the relationships between and among financial ratios solely to develop an empirically-based classification of financial ratios. Using four data sets chosen at six year intervals, they found a stable, seven factor classification system. Stevens (1973) looked for differences in ratio values of acquired firms and non-acquired firms to 
determine if the two groups could be distinguished from one another based upon differences in their financial characteristics. The study used 20 original variables which reduced to a six factor model.

Libby (1975) factor analyzed a set of financial ratios to evaluate the predictive value of ratios and the ability of bank loan officers to utilize the information to predict business failure. A small set of fourteen variables allowed Libby to identify five factors.

Pinches, Eubank, Mingo, and Caruthers (PEMC, 1975) provided further evidence regarding the predictive value of financial statement data. Their work investigated the short-term stability of financial dimensions over a four-year period and found seven stable short-term factors that were useful for predicting bank failures, mergers and acquisitions, and bond ratings.

Using a larger dataset for a single year, Johnson (1978) provided confirming results to PMC and PEMC. Johnson (p. 207) was interested in a, "parsimonious set of ratios from among the diverse array encountered in the literature" for "persons interested in using ratios as either descriptors or predictors of a firm’s financial behavior.” Factor analysis was performed on 61 financial ratios using 1972 data from 306 manufacturing and 159 retail firms. Johnson found there was cross sectional stability of the financial patterns between manufacturing and retail firms. And Johnson found nine ratios (one ratio from each factor) provided substantial explanatory efficiency, when compared with the entire 61 ratios under investigation. Johnson (1979) extended and corroborated his previous results using data from 1972 and 1974 and the same 61 ratios and companies.

Chen and Shimerda (CM, 1981) investigated which ratios were best for a given purpose. They evaluated 26 previous studies which collectively reported 41 ratios that were considered 
useful and/or used by researchers. They asked (p. 51), “Given such a heterogeneous set of useful financial ratios, the decision-maker has to be at a loss in selecting which ratios to use for the task at hand.”

To answer the question and address the decision-maker's challenge CS reviewed five studies that factor analyzed financial ratios. The five studies reviewed were: PM (1973), PMC (1973), Stevens (1973), Libby (1975) and PEMC (1975). The review focused on identifying the common factors and respective ratios used in these studies. The authors demonstrated that each study used the same financial ratio taxonomy consisting of seven factors: financial leverage, capital turnover, return on investment, inventory turnover, receivable turnover, short-term liquidity, and cash position.

Gombola and Ketz (GK, 1983a) extended the research with a comprehensive study that examined 783 manufacturing firms and 88 retail firms over the period 1971 to1980. GK’s (p. 45) purposes were: “... to extend previous studies and financial ratio patterns by examining crossindustry stability of financial ratio patterns. A secondary purpose of the paper is to assess the sensitivity of these patterns to differences in accounting constructs, for example, using net income plus depreciation as a proxy for cash flow." Similarities and differences between factor patterns of manufacturing and retail firms were investigated, as was their stability. GK used the same 48 ratios as PMC, plus ten additional ratios to investigate the efficacy of the accounting constructs. Only companies that reported all the requisite data for all years of the study were included. Unlike most previous studies, GK did not perform log transformations of the ratios since "[f]actor analysis requires no distributional assumptions, allowing usage of non-normally distributed ratios” (p. 47). 
GK reported ten stable factors. Seven of the ten were identical to those reported in CS. The additional factors were: cash flow, cash expenditure, and working capital. The ten additional ratios contributed to the identification of the three additional factors.

In another study using a smaller dataset of 119 firms and 40 ratios, Gombola and Ketz (GK, 1983b) focused specifically on the impact of cash flow measures and price-level adjusted information. This study confirmed the same seven factors identified in the CS reconciliation study and one additional factor, cash flow. The authors hypothesized that the identification of the cash flow factor may have been due to changes in overall economic conditions and/or changes in financial reporting requirements.

Ketz, Doogar, and Jensen (KDJ, 1990) investigated financial ratio taxonomies across industry sectors for the period 1978 to 1987 . Using 32 ratios KDJ identified seven factors that had all been previously identified, including cash flow. Zeller and Stanko (1994) compared accrual based and cash flow based financial ratios using the same 32 ratios. The impetus for the study stemmed from the FASB's adoption of Statement Financial Accounting Standard No. 95, The Statement of Cash Flows. All previous studies (before SFAS 95) had to estimate operating cash flow by adjusting for accrual and deferrals. They identified seven factors, similar to prior studies, including a separate cash flow factor.

Devine and Seaton (DS, 1994/1995) assessed a taxonomy of financial ratios drawn from quarterly data and compared the quarterly results to those obtained from annual information. The primary purposes of the study (p. 81) were, “... to provide an assessment of the stability of the underlying dimension of rational ratios obtained from quarterly information. A second purpose of the study is to compare the quarterly dimensions with those obtained from annual information.” DS did not apply a log transformation to the data. They noted that factor analysis 
studies using log transformations excluded firms with non -positive financial ratios (i.e., negative or zero values) and tainted the sample, thus limiting the generalizability of the findings. DS factor analyzed 44 accounting ratios, drawn from the manufacturing sector, SIC codes 2000 to 3800 for the period 1985 to 1990 . The authors reported a stable twelve factor model for quarterly and annual data. The twelve factors are: leverage, current asset turnover, return on sales, return on equity, fixed asset turnover, return on assets, inventory turnover, capital ratio, working capital turnover, debt ratio, cash turnover, sales velocity. The authors concluded that "the increase in factors from seven to twelve may be the result of admitting firms with negative financial ratios” (p. 84). They further demonstrated that KDJ identified fewer factors because fewer ratios were included in that study.

The literature is silent regarding a taxonomy of financial ratios beyond DS's work. Therefore, changes discussed in the introduction and the lack of follow-up studies beyond DS drive us to ask the follow questions: Have any or all of the original factors survived the changes? Have new factors emerged from the changes? Are the factors stable across this taxonomy?

\section{Research Design}

Data for this study was obtained from Compustat (SIC codes 2100 to 3900, manufacturing sector) for the years 2004 to 2013. We used SIC codes 2100 to 3900 to allow for comparability of our findings to previous empirical work in the exploration of factor patterns. We used the period 2004 to 2013 because it was the most recent data available and provided output to evaluate factor pattern stability over a reasonable period of time. Firms that reported the requisite information in any year of the study were included in our sample for that year, thus preventing a bias toward profitable, leveraged firms (as was noted in PEMC). This selection process also increased the generalizability of our findings (as noted by CS and DS). 
Table 1 identifies the 58 ratios used in our study. We used the same ratios examined by GK (1983a) with two slight modifications. First, we replaced GK’s original ratio, current assets/total debt, with current debt/total debt. The original ratio did not load to any factor in any year of the GK study and the substitution allows us to analyze the relative amount of short-term financing and its correlation to other ratios. Second, we obtained cash flow from operations directly from Compustat, whereas GK had to estimate the amount using an assortment of Compustat variables available at the time of their research.

Insert Table 1 here

Similar to prior research, we used a factor analysis technique called Principle Component Analysis (PCA) to identify factor patterns for each year. PCA is an empirically based, multivariate variable reduction technique that does not rely upon on assumptions about an underling causal model; thus, financial ratio log transformations are not required. Nevertheless, PCA retains the maximum desired amount of information held in the redundant data set.

While previous studies did not provide any evidence on the appropriateness of the data sample for factor analysis, we performed two tests to confirm the validity of conducting factor analysis on the financial ratios. Table 2 shows the test results. The Kaiser-Meyer-Olkin Measure of Sampling Adequacy (MSA) test indicated the proportion of variance in the dataset may be caused by common underlying factors. Across all years, the MSA was greater than 68 percent. Factor analysis is not recommended when the MSA drops below 50 percent. The Bartlett's Test of Sphericity evaluates the hypothesis that the correlation matrix is an identity matrix. We find the p-values are less than .1 percent for each year thus rejecting the null hypothesis of an identity 
matrix at the 5 percent significance level. Rejecting the null hypothesis essentially suggests there is correlation among the ratios.

Insert Table 2 here

We began our analysis with a correlation matrix for the 58 ratios. ${ }^{1}$ We used the correlation matrix rather than the variance-covariance matrix to overcome the significant differences in magnitude across the ratio set. Next, we subjected the matrix to a varimax (orthogonal) rotation to maximize the respective ratio loading on to one factor, while minimizing the respective loadings on all other factors. The subset of ratios with the highest loadings to each factor were used to identify and interpret the information captured by each factor.

Identifying the factors and each factor's respective ratios is a blended process (Laurent 1979, O’Connor 2000, Gordon and Courtney 2013). The objective was to identify stable, interpretable factors that make a substantive contribution to explaining the variance in the ratio set. We defined a factor to be stable if the same ratios loaded to the factor in 8 out of 10 years.

First we evaluated the PCA output against four extraction criteria to set limits on the number of factors that should be evaluated. This step represented a substantial improvement over prior studies, which used a single factor criterion, the Kaiser Eigenvalue greater than one. Consequently, these studies may have truncated the number of factors or included too many

\footnotetext{
${ }^{1}$ We did not subject the ratios to a log transformation. According to GK (1983a) (p. 47), "log transformations are not performed on any ratios. Factor analysis requires no distributional assumptions, allowing usage of non-normally distributed ratios. Also, because no decision model is specified, the variables are not required to take any particular distribution or forms.”
} 
factors. Table 3 identifies the four extraction criteria, along with their respective advantages and disadvantages.

Insert Table 3 here

Next, we required factor loadings to be at an absolute value of .7 or greater (consistent with PMC), and we disregarded factors that had only one ratio loading (consistent with GK 1983b). Ratios whose factor loading was an absolute value less than .7 were not used to identify interpretable, sable factors. Last we evaluated a factor's long-run stability using a congruency coefficient defined by Harman (1976, p. 344) and used by GK (1983a) and Johnson (1978). A congruency coefficient between identified factors in respective years is analogous to a correlation coefficient.

\section{Research Findings}

Table 4 identifies the average number of factors extracted using various extraction criteria and the corresponding amount of explained variance. Our results suggested the number of factors to consider in our PCA ranges between nine and fifteen. Across this range the percentage of explained variance is comparable to previous research, which ranged between 72 to 87 percent.

Examining a range of factor models represents a substantial improvement over prior studies. Prior studies used only the Kaiser $(E V>1)$ criterion. If we had relied solely on the Kaiser criterion, we would not have looked beyond the fifteen factor model. Our analysis, discussed below, showed that a fifteen factor model is sub-optimal.

Insert Table 4 here 
The output required an analysis of several factors models. We investigated a total of seven factor models (nine through fifteen) for each year. We found a twelve factor model provided balance among the different factor extraction criteria, explaining an average of 81 percent of the variance over the ten years in our study. When using fewer than twelve factors, ratios did not consistently load to the same factor, confounding factor identification. Using more than twelve factors resulted in single ratios loaded to a single factor, indicating over extraction. In conclusion, the twelve factor model provided a balance between ratios loading to identifiable factors with substantial explained variance and single ratio loadings to factors resulting in uninterpretable findings. Eleven of the twelve factors exhibited stability. Table 5 lists the respective factors.

Insert Table 5 here

Table 6 reports the mean absolute congruency coefficients of the eleven stable factors identified in Table 5. The interpretation of a congruency coefficient is analogous to a correlation coefficient. The mean absolute congruency coefficient for the factors ranged from .73 to .99, indicating a high level of stability over the ten years.

Insert Table 6 here

Table 7 compares our findings to prior research. We confirmed seven factors identified in prior research. Of the seven, four have been consistently identified beginning with PMC (1973). The four factors are: capital intensiveness (debt ratio), cash position, financial leverage, and 
inventory turnover. The remaining three factors identified are: fund expenditure (cash), return on assets, and working capital. We suspect the ratio selection process is one reason funds expenditure (cash) and working capital factors were not identified in prior research, yet were stable and consistent in this study and GK (1983a). The ratios loading to these factors were not included in studies prior to GK (1983a). This is an important finding. Barnes (1987, p.p. 455456) states that, "A model is only useful for predictive purposes if the underlying relationships and parameters are stable over time. Otherwise it will only be valid for the same period and it cannot be extrapolated into a subsequent period with the same expected performance (Altman and Eisenbeis, 1978).” This finding provides empirical evidence that researchers/analysts can use with confidence the seven factors as a guide in selecting financial ratio variables in predictive modeling and financial analysis.

Insert Table 7 here

Table 8 recaps the specific ratios that consistently loaded to the seven factors. We found that the ratios loading to factors identified in prior studies are comparable to the ratios loading to factors in this study. This finding provides empirical evidence that changes in business practices and reporting requirements have not changed the type of information captured in financial reports and the relationship among the key ratios for the seven previously identified factors.

Insert Table 8 here

Four new factors surfaced in our study. The four are: current position, return on capital, return on equity, and return on sales. A sales turnover factor surfaced in seven of the ten years, falling short of the eight year cutoff we used to identify stability. This finding provides empirical evidence that changes in business practices and reporting requirements have changed the type of 
information captured in financial reports and the relationship among the respective financial ratios. Combined, Tables 7 and 8 provide an empirically based guide for the researcher/analyst with respect to the new factors in selecting attributes for research and analysis.

The results in Tables 7 and 8 raise several questions. The first notable difference is in respect to the cash flow factor identified by GK (1983a) and others. We did not identify a separate cash flow factor. Cash flow ratios loaded to the return on asset factor and return on sales factor, respectively (Table 8). Does this finding negate the unique value of cash flow reporting? If so, this would indicate the need to reinvestigate the value of cash ratios in bank prediction models and/or bond ratings. Have current cash flow management techniques removed the singular value of cash flow information? If so, that might explain why the cash flow ratios in our study loaded to return on assets and return on sales factors. These questions point to areas for further study.

Next, the cash position factor deserves careful consideration. Table 8 recaps the respective ratios loading to this factor. Noteworthy are the ratios, current assets/current debt and quick assets/current debt, which loaded to the cash position factor. Prior studies found that current assets/current debt and quick assets/current debt loaded to a liquidity factor. Our results showed that the liquidity and cash position factors have merged. Improved cash flow, accounts receivable and inventory management techniques enabled by technology appears to have changed the relationships among the respective ratios.

In the present study, a new factor labeled current position surfaced. This factor was identified in every year for the period 2004 to 2013 and exhibited high stability, with a mean absolute congruency coefficient of .93 (Table 6). Two ratios, positively correlated, consistently loaded to the factor: current assets/total assets and current debts/total debt (Table 8). This 
finding indicated there is a strong correlation between the relationship of current asset to total assets and the current debt to total debt. One interpretation may be that management is carefully aligning short and long term assets with short and long term debt. For example, if a company is trying to grow inventory, management is using short term financing to fund the growth. When a company adds long term assets, management finances the acquisition with long term debt. Are technology and changes to business practices enabling manage to do a much better job at controlling the alignment and a more efficient use of working capital? Failure to maintain this relationship may signal a concern, such as using long term debt to finance inventory and/or accounts receivable. We leave to future research to determine if this factor might reflect the changes in financial reporting with regards to fair value, goodwill and other long term assets and liabilities.

Last, the findings clarified a wider perspective regarding financial performance. Previous studies identified a return on investment (profitability) factor, while this study does not (see Table 7). The ratios that loaded to this factor in prior studies spread into four factors in this study: return on capital, return on equity, return on sales, and sales turnover. Table 6 provides evidence that the return on capital, return on equity, and return on sales factors are stable over the period of study, reporting mean absolute congruency coefficients of .73, .78, and .86, respectively. We concluded from this finding that these factors provide unique insight into overall performance of a company. Since the sales turnover factor did not surface in eight or more years in our study, we judged it to be unstable and do not report its factor congruency coefficient.

The current study supports our hypothesis that changes to business practices and financial reporting standards have altered the relationships among performance measures, pointing to 
several questions for future research. How are the relationships underlying the return on capital factor affected by outsourcing and offshoring? Have firms effectively shifted their business model from fixed cost to variable cost? The present study confirms that return on equity is unique from return on investment. How have these factors been affected by management decisions to leverage or de-leverage the business? The return on sales factor certainly calls attention to the common phrase, 'top line growth.' Is this measure useful in predicting firm value?

\section{Conclusion}

This study investigated changes to the financial ratio taxonomy using improved statistical methodology and enhanced research tools that were unavailable to the previous researchers. Our findings confirm prior work but point to an increased taxonomy of financial ratios. Seven factors identified in this study confirm previous work: capital intensiveness (debt ratio), cash position, financial leverage, fund expenditure (cash), inventory turnover, return on assets, and working capital.

Unlike prior studies, we did not find a separate cash flow factor. Whereas prior work identified a single performance factor, we found attributes of performance captured in three separate factors: return on capital, return on equity, and return on sales. In addition, we found the attributes of cash position and liquidity have merged into a single factor. We also found a new factor not identified in prior work, current position, and leave to future research to determine the best uses for this new factor. Our sampling and research design allowed greater generalizability of results than previous studies. 
Table 1: Financial Ratios

\begin{tabular}{|c|c|c|c|}
\hline No. & Ratio & No. & Ratio \\
\hline 1 & Cash/current debt & 30 & Total debt/total assets \\
\hline 2 & Cash/sales & 31 & Working capital/sales \\
\hline 3 & Cash/total assets & 32 & Working capital/total assets \\
\hline 4 & Cash/total debt & 33 & NIPD/equity \\
\hline 5 & Cash flow from operations/equity & 34 & NIPD/sales \\
\hline 6 & Cash flow from operations/sales & 35 & NIPD/total assets \\
\hline 7 & Cash flow from operations/total assets & 36 & WCFO/equity \\
\hline 8 & Cash flow from operations/total debts & 37 & WCFO/sales \\
\hline 9 & Cost of goods sold/inventory & 38 & WCFO/total assets \\
\hline 10 & Cost of goods sold/sales & 39 & NIPD/total capital \\
\hline 11 & Current assets/current debt & 40 & Income/total capital \\
\hline 12 & Current assets/sales & 41 & Current debt/net plant \\
\hline 13 & Current assets/total assets & 42 & Net worth/sales \\
\hline 14 & Current debt/total debt* & 43 & Sales/total assets \\
\hline 15 & EBIT/equity & 44 & Sales/net plant \\
\hline 16 & EBIT/sales & 45 & Sales/total capital \\
\hline 17 & EBIT/total assets & 46 & Sales/working capital \\
\hline 18 & Income/equity & 47 & Total debt/net plant \\
\hline 19 & Income/sales & 48 & Total debt/total capital \\
\hline 20 & Income/total assets & 49 & Total debt/net worth \\
\hline 21 & Inventory/current assets & 50 & Total assets/net worth \\
\hline 22 & Inventory/sales & 51 & Net income/total assets \\
\hline 23 & Inventory/working capital & 52 & Net income/net worth \\
\hline 24 & Long term debt/total assets & 53 & Net income/sales \\
\hline 25 & Quick assets/current debt & 54 & Current debt/net worth \\
\hline 26 & Quick assets/sales & 55 & Quick assets/fund expenditure (accrual) \\
\hline 27 & Quick assets/total assets & 56 & Cash/fund expenditure (accrual) \\
\hline 28 & Receivables/inventory & 57 & Quick assets/fund expenditure (cash) \\
\hline 29 & Receivables/sales & 58 & Cash/fund expenditure (cash) \\
\hline
\end{tabular}

* Revised from current assets/total debt 
Table 2: Descriptive and Adequacy Measures

\begin{tabular}{|c|c|c|c|}
\hline Year & $\begin{array}{c}\text { Sample } \\
\text { Size }\end{array}$ & $\begin{array}{c}\text { Kaiser-Meyer-Olkin } \\
\text { Measure of } \\
\text { Sampling Adequacy } \\
\text { (Required > 50\%) }\end{array}$ & $\begin{array}{c}\text { Bartlett's Test } \\
\text { of Sphericity } \\
\text { P-value } \\
\text { (Required < 5\%) }\end{array}$ \\
\hline $\mathbf{2 0 0 4}$ & 1480 & $70.4 \%$ & $<0.1 \%$ \\
\hline $\mathbf{2 0 0 5}$ & 1534 & $76.0 \%$ & $<0.1 \%$ \\
\hline $\mathbf{2 0 0 6}$ & 1543 & $70.9 \%$ & $<0.1 \%$ \\
\hline $\mathbf{2 0 0 7}$ & 1564 & $69.8 \%$ & $<0.1 \%$ \\
\hline $\mathbf{2 0 0 8}$ & 1555 & $72.8 \%$ & $<0.1 \%$ \\
\hline $\mathbf{2 0 0 9}$ & 1552 & $72.3 \%$ & $<0.1 \%$ \\
\hline $\mathbf{2 0 1 0}$ & 1536 & $79.2 \%$ & $<0.1 \%$ \\
\hline $\mathbf{2 0 1 1}$ & 1484 & $68.4 \%$ & $<0.1 \%$ \\
\hline $\mathbf{2 0 1 2}$ & 1457 & $70.3 \%$ & $<0.1 \%$ \\
\hline $\mathbf{2 0 1 3}$ & 1497 & $69.1 \%$ & $<0.1 \%$ \\
\hline
\end{tabular}


Table 3: Factor Extraction Criteria Advantages and Disadvantages

\begin{tabular}{|l|l|l|}
\hline \multicolumn{1}{|c|}{ Factor extraction criteria } & \multicolumn{1}{|c|}{ Advantages } & \multicolumn{1}{c|}{ Disadvantages } \\
\hline $\begin{array}{l}\text { 1. Total Explained } \\
\text { Variance }\end{array}$ & Flexible & Subjective \\
\hline $\begin{array}{l}\text { 2. Kaiser, also known as } \\
\text { (K1 or EV>1) }\end{array}$ & $\begin{array}{l}\text { Objective, set to simple } \\
\text { predefined limit }\end{array}$ & $\begin{array}{l}\text { Typically overestimates, and } \\
\text { sometimes underestimates the } \\
\text { number of components } \\
\text { (Zwick \& Velicer 1986). } \\
\text { Components not always } \\
\text { reliable (Cliff 1988). }\end{array}$ \\
\hline $\begin{array}{l}\text { 3. Velicer's Minimum } \\
\text { test }\end{array}$ & $\begin{array}{l}\text { Statistically based. } \\
\text { According to O'Connor, } \\
\text { "focus is on the relative } \\
\text { amounts of systematic and } \\
\text { unsystematic variance } \\
\text { remaining in a correlation } \\
\text { matrix." }\end{array}$ & Errs in under extraction \\
\hline $\begin{array}{l}\text { 4. Horn's Parallel Analysis } \\
\text { (PA) }\end{array}$ & $\begin{array}{l}\text { Statistically based. } \\
\text { According to O'Connor, } \\
\text { "focus is on the number of } \\
\text { components that account for } \\
\text { more variance than the } \\
\text { components derived from } \\
\text { random data." }\end{array}$ & Errs in over extraction \\
\hline
\end{tabular}


Table 4: Average Number of Extracted Factors and Percent of Explained Variance

\begin{tabular}{|l|c|c|}
\hline \multirow{2}{*}{ Criterion } & \multicolumn{2}{|c|}{ 2004-2013 average } \\
\cline { 2 - 3 } & $\begin{array}{c}\text { Percent of } \\
\text { Explained Variance }\end{array}$ \\
\hline $\begin{array}{l}\text { Percent of Explained } \\
\text { Variance: }>\text { 70\% }\end{array}$ & 8.80 & 71.99 \\
\hline $\begin{array}{l}\text { Percent of Explained } \\
\text { Variance: }>\text { 75\% }\end{array}$ & 10.10 & 76.16 \\
\hline $\begin{array}{l}\text { Percent of Explained } \\
\text { Variance: }>\text { 80\% }\end{array}$ & 12.00 & 81.36 \\
\hline Kaiser (EV $>\mathbf{1})$ & 14.80 & 87.16 \\
\hline Velicer (MAP) & 12.80 & 80.28 \\
\hline Horn (PA) & 13.60 & 84.90 \\
\hline
\end{tabular}


Table 5: 12-Factor Model Loading by Year (Highlighted are Stable Factors Loading in 8 or More Years)

\begin{tabular}{|c|c|c|c|c|c|c|c|c|c|c|}
\hline \multirow[b]{2}{*}{ Factor } & \multicolumn{10}{|c|}{ Year } \\
\hline & 2004 & 2005 & 2006 & 2007 & 2008 & 2009 & 2010 & 2011 & 2012 & 2013 \\
\hline Ratio with $<.7$ loading & $\mathrm{X}$ & & & & & & $\mathrm{X}$ & $\mathrm{X}$ & & \\
\hline $\begin{array}{l}\text { Factor identified with only } \\
\text { one ratio }\end{array}$ & & & $\mathrm{X}$ & $\mathrm{X}$ & & $\mathrm{X}$ & & & & \\
\hline $\begin{array}{l}\text { 1) } \begin{array}{l}\text { Capital intensiveness } \\
\text { (debt ratio) }\end{array} \\
\end{array}$ & $\mathrm{X}$ & $\mathrm{X}$ & $\mathrm{X}$ & $\mathrm{X}$ & $\mathrm{X}$ & $\mathrm{X}$ & $\mathrm{X}$ & $\mathrm{X}$ & $\mathrm{X}$ & $\mathrm{X}$ \\
\hline 2) Cash position & $\mathrm{X}$ & $\mathrm{X}$ & $\mathrm{X}$ & $\mathrm{X}$ & $\mathrm{X}$ & $\mathrm{X}$ & $\mathrm{X}$ & $\mathrm{X}$ & $\mathrm{X}$ & $\mathrm{X}$ \\
\hline 3) Financial leverage & $\mathrm{X}$ & $\mathrm{X}$ & $\mathrm{X}$ & & $\mathrm{X}$ & & $\mathrm{X}$ & $\mathrm{X}$ & $\mathrm{X}$ & $\mathrm{X}$ \\
\hline $\begin{array}{l}\text { 4) Fund expenditure } \\
\text { (accrual) }\end{array}$ & & $\mathrm{X}$ & & & & & & & & \\
\hline $\begin{array}{l}\text { 5) } \begin{array}{l}\text { Fund expenditure } \\
\text { (cash) }\end{array} \\
\end{array}$ & $\mathrm{X}$ & $\mathrm{X}$ & $\mathrm{X}$ & $\mathrm{X}$ & & $\mathrm{X}$ & $\mathrm{X}$ & $\mathrm{X}$ & $\mathrm{X}$ & $\mathrm{X}$ \\
\hline 6) Inventory turnover & $\mathrm{X}$ & $\mathrm{X}$ & $\mathrm{X}$ & $\mathrm{X}$ & $\mathrm{X}$ & $\mathrm{X}$ & $\mathrm{X}$ & & $\mathrm{X}$ & $\mathrm{X}$ \\
\hline $\begin{array}{l}\text { 7) } \begin{array}{l}\text { Fund expenditure } \\
\text { (cash and accrual) }\end{array} \\
\end{array}$ & & & & & $\mathrm{X}$ & & & & & \\
\hline 8) Current position & $\mathrm{X}$ & $\mathrm{X}$ & $\mathrm{X}$ & $\mathrm{X}$ & $\mathrm{X}$ & $\mathrm{X}$ & $\mathrm{X}$ & $\mathrm{X}$ & $\mathrm{X}$ & $\mathrm{X}$ \\
\hline 9) Return on asset & $\mathrm{X}$ & $\mathrm{X}$ & $\mathrm{X}$ & $\mathrm{X}$ & $\mathrm{X}$ & $\mathrm{X}$ & $\mathrm{X}$ & $\mathrm{X}$ & $\mathrm{X}$ & $\mathrm{X}$ \\
\hline 10) Return on capital & & $\mathrm{X}$ & $\mathrm{X}$ & $\mathrm{X}$ & $\mathrm{X}$ & $\mathrm{X}$ & $\mathrm{X}$ & $\mathrm{X}$ & $\mathrm{X}$ & $\mathrm{X}$ \\
\hline 11) Return on equity & $\mathrm{X}$ & $\mathrm{X}$ & $\mathrm{X}$ & $\mathrm{X}$ & $\mathrm{X}$ & $\mathrm{X}$ & $\mathrm{X}$ & $\mathrm{X}$ & $\mathrm{X}$ & $\mathrm{X}$ \\
\hline 12) Return on sales & $\mathrm{X}$ & $\mathrm{X}$ & $\mathrm{X}$ & $\mathrm{X}$ & $\bar{X}$ & $\mathrm{X}$ & $\mathrm{X}$ & $\mathrm{X}$ & $\mathrm{X}$ & $\mathrm{X}$ \\
\hline 13) Sales turnover & $\mathrm{X}$ & & & $\mathrm{X}$ & $\mathrm{X}$ & $\mathrm{X}$ & & $\mathrm{X}$ & $\mathrm{X}$ & $\mathrm{X}$ \\
\hline 14) Working capital & $\bar{X}$ & $\mathrm{X}$ & $\mathrm{X}$ & $\mathrm{X}$ & $\bar{X}$ & $\mathrm{X}$ & $\mathrm{X}$ & $\mathrm{X}$ & $\mathrm{X}$ & $\mathrm{X}$ \\
\hline Total factors & 12 & 12 & 12 & 12 & 12 & 12 & 12 & 12 & 12 & 12 \\
\hline Explained variance & $80 \%$ & $81 \%$ & $78 \%$ & $82 \%$ & $82 \%$ & $84 \%$ & $85 \%$ & $78 \%$ & $83 \%$ & $79 \%$ \\
\hline & & & vera & expla & va & ce 20 & to 2013 & & & $81 \%$ \\
\hline
\end{tabular}


Table 6: Mean Absolute Congruency Coefficient for Stable Factors

\begin{tabular}{|ll|c|}
\hline \multicolumn{1}{|c|}{ Factor Number and Name } & $\begin{array}{c}\text { Mean Absolute } \\
\text { Congruency Coefficient }\end{array}$ \\
\hline 1) & Capital intensiveness (debt ratio) & .85 \\
\hline 2) & Cash position & .95 \\
\hline 3) & Financial leverage & .79 \\
\hline 5) & Fund expenditure (cash) & .89 \\
\hline 6) & Inventory turnover & .93 \\
\hline 8) & Current position & .93 \\
\hline 9) & Return on asset & .95 \\
\hline 10) & Return on capital & .73 \\
\hline 11) & Return on equity & .78 \\
\hline 12) & Return on sales & .86 \\
\hline 14) & Working capital & .99 \\
\hline
\end{tabular}


Table 7: Comparison of Prior Studies to Current Study (Highlighted Factors Were Identified in Previous Studies)

\begin{tabular}{|c|c|c|c|c|c|}
\hline $\begin{array}{l}\text { Study } \\
\text { Number of ratios used } \\
\text { Factor name }\end{array}$ & $\begin{array}{c}\text { PMC (1973) } \\
48^{*}\end{array}$ & $\begin{array}{c}\text { PEMC (1975) } \\
\text { 48* }\end{array}$ & $\begin{array}{c}\text { Johnson (1978) } \\
61^{*}\end{array}$ & $\begin{array}{c}\text { GK (1983a) } \\
58\end{array}$ & $\begin{array}{c}\text { Current Study } \\
\text { (58) } \\
\text { [Number of years } \\
\text { factor identified] }\end{array}$ \\
\hline Cash flow & & & & $\mathrm{X}$ & \\
\hline Capital intensiveness (debt ratio) & $\mathrm{X}$ & $\mathrm{X}$ & $\mathrm{X}$ & $\mathrm{X}$ & $\mathrm{X}[10]$ \\
\hline Cash position & $\mathrm{X}$ & $\mathrm{X}$ & $\mathrm{X}$ & $\mathrm{X}$ & $\mathrm{X}[10]$ \\
\hline Current position & & & & & $\mathrm{X}[10]$ \\
\hline Financial leverage & $\mathrm{X}$ & $\mathrm{X}$ & $\mathrm{X}$ & $\mathrm{X}$ & $\mathrm{X}[8]$ \\
\hline Decomposition measures & & & $\mathrm{X}$ & & \\
\hline Fund expenditure (accrual) & & & & & $\mathrm{X}[1]$ \\
\hline Fund expenditure (cash and accrual) & & & & & $\mathrm{X}[1]$ \\
\hline Fund expenditure (cash) & & & & $\mathrm{X}$ & $\mathrm{X}[10]$ \\
\hline Inventory turnover & $\mathrm{X}$ & $\mathrm{X}$ & $\mathrm{X}$ & $\mathrm{X}$ & $\mathrm{X}[9]$ \\
\hline Liquidity & $\mathrm{X}$ & $\mathrm{X}$ & $\mathrm{X}$ & $\mathrm{X}$ & \\
\hline Loose ends & & & $\mathrm{X}$ & & \\
\hline Receivable intensiveness & $\mathrm{X}$ & $\mathrm{X}$ & $\mathrm{X}$ & & \\
\hline Return on capital & & & & & $\mathrm{X}[9]$ \\
\hline Return on investment (Profitability) & $\mathrm{X}$ & $\mathrm{X}$ & $\mathrm{X}$ & $\mathrm{X}$ & \\
\hline Return on equity & & & & & $\mathrm{X}[10]$ \\
\hline Return on sales & & & & & $\mathrm{X}[10]$ \\
\hline Sales turnover & & & & & $\mathrm{X}[7]$ \\
\hline Working capital & & & & $\mathrm{X}$ & $\mathrm{X}[10]$ \\
\hline
\end{tabular}

*Applied a log transformation 
Table 8: Ratios Loading to Respective Factors

\section{[Years in Brackets Indicate Years When Ratio Did Not Load]}

\begin{tabular}{|c|c|c|c|}
\hline Capital intensiveness (debt ratio) & & $\underline{\text { Return on asset }}$ & \\
\hline Current debt/ net plant & All years & Cash flow/ total assets & 9 of 10 [2007] \\
\hline Total debt/ net plant & All years & EBIT/ total assets & All years \\
\hline Cash position & & Income/ total assets & All years \\
\hline Cash/ current debt & All years & Long term debt/ total assets & 9 of 10 [2004] \\
\hline Cash/ total debt & All years & Net income/ total assets & All years \\
\hline Current assets/ current debt & All years & NIPD/ total assets & All years \\
\hline Quick assets/ current debt & All years & Total debt/ total assets & 9 of 10 [2004\} \\
\hline Financial leverage & & WCFO/ total assets & 8 of 10 [2005, 2013] \\
\hline Current debt/ net worth & 8 of 10 [2007, 2009] & Working capital/ total assets & 9 of 10 [2004] \\
\hline Total assets/ net worth & 8 of 10 [2007, 2009] & $\underline{\text { Return on capital }}$ & \\
\hline Total debt/ net worth & 8 of 10 [2007, 2009] & Income/ total capital & 8 of 10 [2004, 2010] \\
\hline Fund expenditure (cash) & & NIPD/ total capital & 8 of 10 [2004, 2010] \\
\hline Cash/ fund expenditure (cash) & 9 of 10 [2008] & Sales/ total capital & 8 of 10 [2004] \\
\hline Quick assets/ fund expenditure (cash) & 9 of 10 [2008] & Total debt/ total capital & All years \\
\hline Inventory turnover & & $\underline{\text { Return on equity }}$ & \\
\hline Cost of goods sold/ inventory & 9 of 10 [2011] & EBIT/ equity & All years \\
\hline Receivables/ inventory & 9 of 10 [2011] & Income/ equity & All years \\
\hline Current position & & Net income/ net worth & All years \\
\hline Current assets/ total assets & All & NIPD/ equity & All years \\
\hline Current debts/ total debt & 7 of 10 [2008, 2012, 2013] & $\underline{\text { Return on sales }}$ & \\
\hline Working capital & & Cash flow/ sales & All years \\
\hline Inventory/ working capital & All years & EBIT/ sales & All years \\
\hline \multirow[t]{4}{*}{ Sales/ working capital } & All years & Income/ sales & 9 of 10 [2010] \\
\hline & & Net income/ sales & 9 of 10 [2010] \\
\hline & & NIPD/ sales & 9 of 10 [2010] \\
\hline & & WCFO/ sales & All years \\
\hline
\end{tabular}




\section{References}

Altman, E., \& R. Eisenbeis (1978). Financial Applications of Discriminant Analysis: A Clarification, Journal of Financial and Quantitative Analysis, 13(1), 185-195.

Barnes, B. (1987). The Analysis and Use of Financial Ratios: A Review Article, Journal of Business Finance \& Accounting, 14(4), 449-461.

Chen, K. H., \& T. A. Shimerda (1981). An Empirical Analysis of Useful Financial Ratios. Financial Management, 10(1), 51-61.

Cliff, N. (1988). The Eigenvalues-Greater-Than-One Rule and the Reliability of Components: Psychological Bulletin, 48, 687-692.

Devine, K., \& L. Seaton (1994/1995, Winter). A Examination of Quarterly Financial Ratio Stability: Implictions for Financial Deciion Making. Journal of Applied Business Research, 11(1), 81-97.

Gombola, M., \& J. Ketz (1983a), Financial Ratio Patterns in Retail and Manufacturing Organizations. Financial Management (12), 45-56.

Gombola, M., \& J. Ketz (1983b). A Note on Cash Flow and classification Patterns of Finacial Ratios. The Accounting Review, LVIII(1), 105-114.

Gordon, M., \& R. Courtney (2013). Determining the number of factors to retain in EFA: Using the SPSS R-menu v2.0 to make more juidicious estimations. Practical Assessment Research \& Evaluation, 18(8), pp. 1-14.

Harman, H. H. Modern Factor Analysis. University of Chicago Press, 1976.

Johnson, W. B. (1978). The Cross-Sectional Stability of Financial Patterns. Journal of Business Finance \& Accounting, 5(2), 207 - 213.

Johnson, W.B. (1979).The Cross-Sectional Stability of Financial Ratio Patterns. Journal of Financial and Quantitative Analysis, Vol. XIV, No. 5.

Kaiser, H. (1970). A Second Generation Little Jiffy. Psychometrika, 34(4), 401 - 415.

Kaiser, H., \& J. Rice (1974). Little Jiffy, Mark IV. Educational and Psychological Measurement, 34(1), 111 - 117.

Ketz, J., R. Doogar \& D. Jensen. A Cross-Industry Analysis of Financial Ratios: Comparabilities and Corporate Performance. New York, Quorum Books, 1990.

Laurent, C. R. (1979). Improving the Efficiency and Effectiveness of Financial Ratio Analysis. Journal of Business Finance \& Accounting, 6(3), 401.

Libby, R. (1975, Spring). Accounting Ratios and the Prediction of Failure: Some Behavioral Evidence. Journal of Accounting Research, 150-161. 
O'Connor, B. P. (2000). SPSS and SAS programs for determing the number of components using parallel analysis and Velicer's MAP test. Behaviour reserach Methods, Instruments, \& Computers, 32, pp. 396 - 402.

Pinches, G. E., \& K. A. Mingo (1973, March). A Multivariate Analysis of Industrial Bond Ratings. Journal of Finance, 1-18.

Pinches, G. E., A. A. Eubank, K. A. Mingo, \& J. K. Caruthers, J. K. (1975, October). The Hierarchical Classification of Financial Ratios. Journal of Business Research, 3(4), 295-309.

Pinches, G. E., K. A. Mingo, \& J. K. Caruther (1973). The Stability of Financial Patterns In Industrial Organizations. The Journal of Finance, 28(2), 389-396.

Stevens, D. L. (1973, March). Financial Characteristics of Merged Firms: A Multivariate Analysis. Journal of Financial and Quantitative Analysts, 149-158.

Zeller, T. L., \& B. B. Stanko (1994). Cash Flow and the New Taxonomy of Financial Ratios for Manufacturing Firms. The Southern Business \& Economic Journal, 17(2), 85-99.

Zwick, W. R., \& W. F. Velicer (1986). Comparisons of Five Rules for Determining the Number of Componets to Retain. Psychological Bulletin, 99(3), 432-442. 